\title{
KEMAMPUAN KERJA PEGAWAI SEKRETARIAT DAERAH KABUPATEN BARRU
}

\section{WORK ABILITY OF REGIONAL SECRETARIAT EMPLOYEES BARRU REGENCY}

\author{
Anirwan* \\ * Ilmu Pemerintahan Universitas Pancasakti Makassar \\ Email : anirwan.science@gmail.com
}

\begin{abstract}
Employee performance is largely determined by individual workability. The performance of employees at the Barru Regency Regional Secretariat is still not optimal. By that the purpose of this study is to know and analyze the Work Capability of the Regional Secretariat of the Barru Regency, from the aspects of engineering, health, knowledge and skills of employees. The research method used is a qualitative descriptive method. This qualitative research method is used because the research conducted is only descriptive, namely the author wants to describe, the Work Capability of Barru Regency Regional Secretariat Employees. Techniques for collecting data through interviews, observation and document review. The results of the study showed that the work capacity of the Barru Regency Regional Secretariat employees was not optimal in terms of competence, employee health conditions, employee knowledge and skills. Employee competence has not been maximized due to lack of knowledge and skills possessed so that they are less skilled and capable in carrying out their duties. While the health condition is very influential on the performance of employees because the health of good employees will facilitate the work that is their duty and responsibility.
\end{abstract}

Keywords: Work Ability (competence, health, knowledge, skills)

\begin{abstract}
ABSTRAK
Kinerja pegawai sangat ditentukan dari kemampuan kerja individu. Kinerja pegawai pada Sekretariat Daerah Kabupaten Barru masih belum optimal. Olehnya itu, tujuan penelitian ini adalah untuk menganalisis Kemampuan Kerja Pegawai Sekretariat Daerah Kabupaten Barru, dari aspek kopeteni, kesehatan, pengetahuan, dan keterampilan pegawai. Metode penelitian yang digunakan adalah metode deskriptif kualitatif. Metode penelitian kualitatif ini digunakan karena penelitian yang dilakukan hanya bersifat deskriptif, yaitu penulis ingin menggambarkan, Kemampuan Kerja Pegawai Sekretariat Daerah Kabupaten Barru. Teknik pengumpulan data melalui wawancara, observasi dan telaah dokumen. Hasil penelitian menunjukkan bahwa kemampuan kerja pegawai Sekretariat Daerah Kabupaten Barru belum optimal dilihat dari kompetensi, kondisi kesehatan pegawai, pengetahuan dan keterampilan pegawai. Kompentensi pegawai belum maksimal yang disebabkan karena kurangnya pengetahuan dan keterampilan yang dimiliki, sehingga kurang terampil dan cakap dalam menjalankan tugasnya. Sedangkan kondisi kesehatan sangat berpengaruh terhadap kinerja pegawai karena
\end{abstract}

Journal of Governance and Local Politics (JGLP)

ISSN (online): 2684-9992, Vol: 1, Nomor: 1, Mei 2019 
kesehatan pegawai yang baik akan memperlancar pekerjaan yang menjadi tugas dan tanggungjawabnya.

Kata Kunci: Kemampuan Kerja (kompetensi, kesehatan, pengetahuan, keterampilan)

\section{PENDAHULUAN}

Sumber daya manusia merupakan faktor penting bagi setiap organisasi, sebab tanpa sumber daya manusia tujuan dan sasaran organisasi tidak akan tercapai sesuai yang direncanakan. Oleh karena itu, peranan sumber daya manusia sangat penting dalam setiap organisasi. Pentingnya peranan sumber daya manusia bagi setiap organisasi diharapkan dapat meningkatkan kinerja pegawai. Untuk itu sumber daya manusia perlu memiliki skill atau keterampilan yang handal dalam menangani setiap pekerjaan, sebab dengan adanya skill yang handal maka secara langsung dapat meningkatkan kinerja pegawai.

Setiap organisasi pasti memiliki tujuan yang ingin dicapai, diperlukan sumber daya yang maksimal agar tercapainya tujuan organisasi tersebut. Sumber daya yang terpenting dari sebuah organisasi adalah sumbar daya manusia. Orang-orang yang memberikan tenaga, bakat, kreativitas dan usaha mereka kepada organisasi. Oleh karena itu, pegawai merupakan kunci penentu keberhasilan organisasi. Setiap pegawai selain dituntut untuk memiliki pengetahuan, dan kompetensi, juga harus mempunyai pengalaman, motivasi, komitmen yang tinggi, disiplin diri, dan semangat kerja tinggi.

Faktor penting dalam keberhasilan suatu organisasi adalah adanya pegawai yang mampu dan terampil serta mempunyai semangat kerja yang tinggi, sehingga dapat diharapkan suatu hasil kerja yang memuaskan. Kenyataannya tidak semua pegawai mempunyai kemampuan dan keterampilan serta semangat kerja sesuai dengan harapan organisasi. Seorang pegawai yang mempunyai kemampuan sesuai dengan harapan organisasi, kadang-kadang 
tidak mempunyai semangat kerja tinggi sehingga kinerjanya tidak sesuai dengan yang diharapkan.

Pegawai Negeri Sipil dianggap sebagai penunjang pelaksanaan pembangunan dalam bidang administrasi pemerintah, maka kedudukan dan peranan Pegawai Negeri Sipil adalah penting dan menentukan, karena Pegawai Negeri Sipil adalah unsur aparatur negara, untuk menyelenggarakan pemerintahan pembangunan dalam rangka mencapai tujuan nasional.

Kinerja seorang pegawai akan menentukan kinerja dari organisasi dimana ia bekerja. Tugas masing-masing individu/pegawai secara keseluruhan akan berpengaruh terhadap kinerja organisasi tersebut, oleh karena itu para pegawai dalam organisasi harus memiliki kompetensi yang baik agar roda organisasi dapat berjalan dengan baik. Tentunya masing-masing pegawai memiliki kemampuannya tersendiri. Kemampuan individualnya tersebut akan mempengaruhi bagaimana sikap dan perilaku pegawai dalam memecahkan permasalahan pekerjaanya.

Berdasarkan Laporan Penyelenggaraan Pemerintahan Daerah (LPPD) Kabupaten Barru sesuai ketentuan Peraturan Pemerintah Nomor 3 tahun 2007 tentang Laporan Penyelenggaraan Pemerintahan Daerah (LPPD) kepada pemerintah, Laporan Keterangan Pertanggungjawaban (LKPJ) kepada DPRD dan Informasi Laporan penyelenggaraan Pemerintahan Daerah (ILPPD) kepada masyarakat. Bagi pemerintah, LPPD adalah merupakan salah satu bahan evaluasi untuk keperluan pembinaan terhadap pemerintahan daerah. Untuk wujud pelaksanaan otonomi daerah sejalan dengan upaya menciptakan pemerintahan yang bersih, bertanggungjawab serta mampu menjawab tuntutan perubahan secara efektif dan efisien dengan prinsip tata pemerintahan yang baik.

Sekretariat Daerah merupakan salah satu Satuan Kerja Perangkat Daerah dalam lingkup Pemerintah Daerah Kabupaten Barru yang bertanggung jawab 
kepada Bupati dan dasar hukum pembentukannya adalah Peraturan Daerah Kabupaten Barru Nomor 4 Tahun 2008 tentang Pembentukan Organisasi dan Tata Kerja Sekretariat Daerah dan Sekretariat Dewan Perwakilan Rakyat Daerah Kabupaten Barru.

Namun dalam pelaksanaan tugas pokok dan fungsi bagian -bagian dalam lingkup Sekretariat Daerah Kabupaten Barru belum optimal. Hal ini dapat diketahui bahwa terkhusus sekretariat daerah sebagai pelaksana urusan pemerintahan umum di kabupaten Barru, terdapat 16 (enam belas) program dan kegiatan prioritas meliputi : 1). Program peningkatan kerjasama antar pemerintahan daerah, 2). Program penerapan kepemerintahan yang baik, 3). Program pemberdayaan potensi keamanan, 4). Program peningkatan pelayanan kedinasan kepala daerah/wakil kepala daerah, 5). Program peningkatan kerukunan umat beragama, 6). Program peningkatan sistem pengawasan internal dan pengendalian pelaksanaan kebijakan kepala daerah, 7). Program peningkatan kerjasama antar pemerintahan daerah, 8). Program penataan peraturan perundang-undangan, 9). Program peningkatan kesadaran hukum dan hak asasi manusia, 10). Program penataan kelembagaan dan ketatalaksanaan, 11). Program peningkatan dan pengembangan pengelolaan keuangan daerah, 12). Program peningkatan kapasitas lembaga perwakilan rakyat daerah, 13). Program peningkatan sistem pengawasan internal dan pengendalian pelaksanaan kebijakan kepala daerah, 14). Program peningkatan profesionalisme tenaga pemeriksa dan aparatur pengawasan, 15). Program mengintensifkan penanganan pengaduan masyarakat, dan 16). Program pengembangan otonomi daerah.

Kemampuan pegawai Sekretariat Daerah Kabupaten Barru masih rendah, ditandai dengan terdapat beberapa pegawai sering menumpuk pekerjaannya. motivasi pegawai sangat rendah yang ditandai dengan adanya pegawai yang malas dan mangkir dari tempat kerja pada saat jam kerja, serta komitmen 
pegawai kurang baik yang ditandai dengan banyaknya pegawai yang tidak menyelesaikan pekerjaan tepat waktu. Kurangnya kecakapan belum menunjukkan keterampilan secara profesional. Termasuk masih ditemukan pegawai kurang menguasai bidang kerja yang dibebankan karena kurangnya pengalaman kerja, sikap kerja yang kurang profesional dan penguasaan teknologi yang masih rendah. Hal ini juga tidak terlepas dari masih rendahnya disiplin dan profesionalisme aparat, masih tendahnya pemahaman terhadap tugas pokok dan fungsi.

Rendahnya kinerja pegawai Sekretariat Daerah kabupaten Barru disebabkan tingkat pendidikan kadang tidak sesuai dengan penempatannya dan beda latar belakang pendidikan dengan pekerjaan sehari-hari, tugas pokok dan fungsinya kadang tidak sesuai, kurangnya personil khususnya staf fungsional umum pada tiap sub bagian yang ada dalam lingkungan sekretariat pada bagian tertentu kelebihan staf fungsional umum. Oleh karena itu, tujuan penelitian ini adalah untuk mengetahui dan menganalisis kemampuan kerja Pegawai Sekretariat Daerah Kabupaten Barru.

\section{METODE PENELITIAN}

Metode penelitian yang digunakan adalah metode deskriptif kualitatif dengan teknik pengumpulan data melalui wawancara, observasi dan telaah dokumen. Data hasil penelitian data dianalisis dengan analisis kualitatif yang dilakukan melalui lima tahapan yaitu tahap pengumpulan data, reduksi data, display data, verifikasi data, dan penarikan kesimpulan.

\section{HASIL DAN DISKUSI}

Kemampuan tergantung pada keterampilan dan pengetahuan (ability depends upon both skill and knowledge): dua unsur yaitu pengetahuan dan keterampilan merupakan pencerminan dari kemampuan yang diperoleh dari 
pendidikan formal, informal dan non-formal yang dapat menunjang peningkatan kecakapan. Kemampuan kerja seorang pegawai dalam suatu organisasi itu, dapat dipengaruhi oleh dua hal, yaitu faktor pengetahuan yang dimiliki seseorang atau dimiliki pegawai yang bersangkutan serta faktor tingkat keterampilan yang dimiliki pegawai dalam menunjang atau membantu pelaksanaan pekerjaan yang diberikan atau dibebankan kepada pegawai tersebut. Robbins (2006) mengatakan bahwa kemampuan merujuk ke kapasitas individu untuk mengerjakan berbagai tugas dalam pekerjaan tertentu. Kemampuan keseluruhan seseorang pada hakikatnya tersusun dari dua faktor: kemampuan intelektual dan kemampuan fisik. Robbins menegaskan bahwa kemampuan seseorang didasari atas dua farktor penentu, yakni faktor intelektual yang diperoleh melalui pendidikan formal dan non-formal, dan faktor kemampuan fisik menyangkut kesehatan jasmani dan rohani. Kedua faktor ini menentukan kapasitas individu dalam suatu organisasi. Adapun pembahasan lebih rinci terkait indikator penelitian adalah sebagai berikut :

\section{Kompetensi Pegawai}

Kompetensi yaitu sifat dasar yang dimiliki atau bagian kepribadian yang mendalam dan melekat kepada seseorang serta perilaku yang dapat diprediksi pada berbagai keadaan dan tugas pekerjaan sebagai dorongan untuk mempunyai prestasi dan keinginan berusaha agar melaksanakan tugas dengan efektif. Ketidaksesuaian dalam kompetensi-kompetensi inilah yang membedakan seorang pelaku unggul dari pelaku yang berprestasi terbatas. Kompetensi terbatas dan kompetensi istimewa untuk suatu pekerjaan tertentu merupakan pola atau pedoman dalam pemilihan karyawan (personal selection), perencanaan pengalihan tugas (succession planning), penilaian kerja (performance appraisal) dan pengembangan (development).

Dengan kata lain, kompetensi adalah penguasaan terhadap seperangkat pengetahuan, keterampilan, nilai nilai dan sikap yang mengarah kepada kinerja 
dan direfleksikan dalam kebiasaan berpikir dan bertindak sesuai dengan profesinya. Dengan demikian kompetensi menunjukkan keterampilan atau pengetahuan yang dicirikan oleh profesionalisme dalam suatu bidang tertentu sebagai suatu yang terpenting. Kompetensi sebagai karakteristik seseorang berhubungan dengan kinerja yang efektif dalam suatu pekerjaan atau situasi. Menurut Spencer dan Spencer (1993) mengemukakan bahwa kompetensi sebagai "karakter sikap dan perilaku, atau kemampuan individual yang relatif bersifat stabil ketika menghadapi suatu situasi di tempat kerja, yang terbentuk dari sinerji antara watak, konsep diri, motivasi internal, serta kapasitas pengetahuan kontekstual".

Fokus kompetensi adalah untuk memanfaatkan pengetahuan dan ketrampilan kerja guna mencapai kinerja optimal. Dengan demikian kompetensi adalah segala sesuatu yang dimiliki oleh seseorang berupa pengetahuan ketrampilan dan faktor-faktor internal individu lainnya untuk dapat mengerjakan sesuatu pekerjaan. Dengan kata lain, kompetensi adalah kemampuan melaksanakan tugas berdasarkan pengetahuan dan ketrampilan yang dimiliki setiap individu.

Analisis hasil wawancara mengambarkan bahwa tingkat pendidikan pegawai sudah barang tentu akan berpengaruh terhadap kinerja pada bidangnya masing-masing. Maka tingkat pendidikan sangat berpengaruh terhadap kinerja pegawai dikaitkan dengan tugasnya. Lebih lanjut hasil wawancara menegaskan bahwa pendidikan dan pengalaman dalam bekerja memiliki pengaruh dan keterkaitan yang erat. pendidikan yang tinggi dan berkualitas dipadukan dengan pengalaman akan memberikan kualitas kinerja yang baik dari hasil kerja pegawai.

Kemudian analisis hasil wawancara menegaskan bahwa pegawai harus memperhatikan tingkat pendidikannya dan berupaya melakukan peningkatan mutu kerja, dengan demikian akan memberikan pengaruh besar terhadap 
peningkatan kompetensi dan kemampuan kerja yang optimal. Selanjutnya analisis hasil wawancara menegaskan bahwa biaya Bimtek yang diberikan kepada pegawai dalam upaya peningkatan kapasitas SDM secara langsung akan memberikan pengaruh terhadap peningkatan kompetensi dan kemampuan seseorang. Sehingga pemberian biaya Bimtek dianggap sanga efektif dalam rangka meningkatkan mutu dan kinerja seseorang.

Analisis hasil wawancara menegaskan bahwa dalam penempatan pegawai yang dianggap sesuai dengan kemampuan dan bidang menjadi sangat penting. Dalam sebuah organisasi atau lembaga, penempatan seseorang yang tidak sesuai dengan bidang dan kompetensinya bahkan dianggap not the right man, not in the right place and even not in the right time. Oleh karena itu, pendelegasian tugas kerja dan kewenangan harus sesuai dengan kemampuan dan kompetensi seseorang dengan tujuan peningkatan kualitas kinerja yang baik. Kemudian analisis hasil wawancara menegaskan bahwa Penyelenggaraan Diklat yang salah satu tujuannya yakni sebagai upaya meningkatkan kualitas SDM pegawai. Kinerja yang baik tidak akan terlaksana tanpa adanya peningkatan kemampuan dan kompetensi yang nantinya akan berpengaruh langsung terhadap pelaksanaan tugas dan tupoksinya masing-masing-masing.

Dapat simpulkan bahwa kompetensi pegawai Sekretariat Daerah Kabupaten Barru sangat berpengaruh terhadap kinerja pegawai melalui Bimbingan Teknis dan Diklat yang telah diikuti sesuai dengan tugas pokok dan fungsinya. Namun dalam penempatan pegawai masih kurang sesuai dengan latar belakang pendidikannya, sehingga masih terdapat pegawai belum mampu menjalankan tugasnya dengan baik.

\section{Kondisi Kesehatan Pegawai}

Kesehatan dalam Undang-undang Nomor 36 Tahun 2009 tentang Kesehatan adalah keadaan sehat, baik secara fisik, mental, spritual maupun sosial yang memungkinkan setiap orang untuk hidup produktif secara sosial dan 
ekonomis. Pasal 4 UU Kesehatan menegaskan bahwa Setiap orang berhak atas kesehatan. Berpegang pada ketentuan tersebut setiap pegawai Negeri beserta keluarganya berhak pula atas derajat kesehatan yang optimal. Undang-undang tentang Kepegawaian Negeri menyatakan: "setiap Pegawai Negeri dan keluarganya pada waktu sakit dan melahirkan anak berhak mendapat bantuan dan setiap pegawai negeri, apabila mendapat kecelakaan dan/atau cacat ataupun meninggal dunia mendapat bantuan.

Derajat kesehatan yang optimal dapat dicapai dengan terpenuhinya: pangan yang memenuhi syarat kesehatan, sandang yang memadai, perumahan dan transportasi yang memenuhi syarat kesehatan, pemeliharaan kesehatan dan pencegahan penyakit, pengobatan dan perawatan penyakit, penyediaan obatobatan, pendidikan dan pelatihan tentang kesehatan. Jelas bahwa derajat kesehatan yang optimal pada pegawai negeri tidak cukup hanya dicapai dengan upaya khusus medis semata, tapi titik berat justru di bidang yang lain yaitu pangan, perumahan, transportasi yang pada akhirnya tergantung dari gaji dan jaminan kesejahteraan lainnya.

Kesehatan pegawai negeri terutama bertitik tolak pada terselenggaranya kesehatan minimum, melalui upaya pemeliharaan kesehatan serta upaya kesehatan preventif, kuratif, dan rehabilitatif, yang penyelenggaraannya dilakukan melalui sistem asuransi sehingga pegawai negeri tidak usah membayar langsung sendiri. Adapun upaya kesehatan dan higiene kerja yang antara lain beraspek mencegah kelelahan kerja, meningkatkan efisiensi telah mulai dalam taraf perhatian dan dilaksanakan oleh masing-masing instansi menurut keperluan. Upaya menerapkan kesehatan kerja oleh instansi yang bersangkutan berdasarkan alasan tentang besar dan mendesaknya kebutuhan untuk meningkatkan efisiensi dan produktivitas pelayanan sektor pemerintah. Untuk itu kegiatan yang bersifat memelopori upaya kesehatan dan higienes kerja 
telah banyak dimulai. Masih perlu cukup waktu untuk menyaksikan hasil spektakuler dari upaya tersebut.

Analisis hasil wawancara menegaskan bahwa kondisi kesehatan pegawai dianggap berpengaruh besar terhadap kinerja pegawai. Kualitas kesehatan yang baik dan prima dari setiap pegawai akan meningkatkan mutu kerja dan kompetensi seorang dengan lebih cepat. Tanpa kualitas kesehatan yang baik maka akan berdampak kurang optimal terhadap kinerja. Kesehatan baik tentunya akan mendorong semangat kerja pegawai, karena kesehatan pegawai yang baik sangat penting diperhatikan akan kinerja pegawai lebih baik pula, untuk itu, perlu menjadi perhatian bagi pimpinan Sekretariat Daerah Kabupaten Barru terhadap kondisi kesehatan pegawainya dengan memberikan jaminan Kesehatan bagi pegawai agar kondisi kesehatan pegawai tetap fit dalam bekerja sehingga pekerjaan pegawai dapat berjalan lancar.

Lebih lanjut analisis hasil wawancara menegaskan bahwa kesehatan pegawai tidak terlalu berpengaruh terhadap pekerjaan pegawai karena pekerjaan pegawai yang tertunda tidak akan diambil alih oleh pegawai yang lainnya sehigga tidak terlalu mempengaruhi kinerja pegawai. Tugas pokok dan fungsi pegawai merupakan tanggung jawab pegawai masing-masing sehingga masing-masing pegawai bertanggung jawab atas penyelesaian pekerjaan masing-masing pegawai.

Dapat disimpulkan bahwa kondisi kesehatan pegawai memiliki pengaruh terhadap kinerja pegawai karena pekerjaan yan menjadi tugas dan fungsi pokok pegawai merupakan tanggung jawab masing-masing pegawai sehingga pekerjaan yang terbengkalai dikerjakan oleh masing-masing. Hal ini tentunya sangat berdampak pada kelancaran pelayanan terhadap masyarakat. Keterlambatan dalam pemberian pelayanan menjadikan masyarakat kurang merasa puas dengan pelayanan yang diberikan. 


\section{Pengetahuan Pegawai}

Peningkatan kompetensi sumber daya manusia sangat ditentukan oleh pengetahuan. Pengetahuan menjadi syarat mutlak untuk diperhatikan, karena menjadi tolok ukur dalam meningkatkan pengembangan kompetensi sumber daya manusia. Pengetahuan juga didapat dari proses pendidikan formal pegawai itu sendiri, dimana makin tinggi tingkat pendidikan seseorang, maka besar kemungkinan menunjang pengetahuannya dalam meningkatkan kompetensinya. Suatu jenis pengetahuan yang dimiliki pegawai yang didapatkan dari proses belajar serta bisa juga dari pengalaman, dari proses yang didapat akan mampu menunjang pegawai dalam meningkatkan kemampuannya dalam menyelesaikan pekerjaan. Menurut Subagyo dalam (Mangkunegara, 2000), bahwa "pengetahuan pegawai merupakan segala sesuatu yang mereka ketahui tentang objek tertentu yang merupakan pengetahuan umum yang dilaksanakan secara langsung atau mempengaruhi pelaksanaan tugas pegawai".

Analisis hasil wawancara menegaskan bahwa pengetahuan pegawai sangat berpengaruh terhadap kinerja pegawai. Pengatuhuan pegawai yang minim akan berdampak pada kinerja karena kurangnya pengetahuan terhadap pekerjaanya tentunya membuat pegawai kurang terampil dan cakap dalam melaksanakan tugasnya. Lebih lanjut analisis hasil wawancara menegaskan bahwa latar belakang pendidikan pegawai sangat bepengaruh terhadap kinerja pegawai. Penempatan pegawai sesuai dengan latar belakang pendidikan pegawai tentunya akan mempengaruhi terhadap pelaksanaan tugasnya. Olehnya itu, pekerjaan yang menjadi tugas dan tanggung jawab pegawai dapat dikerjakan dengan baik dengan kesesuain latar belakang pendidikanya dengan bidang kerja pegawai.

Selanjutnya analisis hasil wawancara menegaskan bahwa walaupun latar belakang pendidikan pegawai kurang sesuai dengan bidang kerjanya. Akan tetapi pekerjaaan yang menjadi tanggung jawab pegawai dapat dilaksanakan 
dengan baik. Hal ini dikarenakan pengalaman kerja pegawai yang banyak dan tergolong lama sehingga pegawai mahir menjalankan tugasnya. Kemudian analisis hasil wawancara menegaskan bahwa meningkatkan pengetahuan pegawai maka, individu perlu terus menambah pengetahuannya agar dapat lebih memahami tugas dan pekerjaannya dengan baik. Pengetahuan pegawai yang dimiliki sangat berpengaruh terhadap kinerjanya. Olehnya itu pegawai harus terus meningkatkan pengetahuannya agar semua pekerjaan yang menjadi tugasnya dapat dilaskanakan dengan baik.

Lebih lanjut analisis hasil wawancara menegaskan bahwa jenjang kepangkatan dan loyalitas pegawai juga juga berpegaruh terhadap kinerja pegawai. Olehnya itu peningkatan pengetahuan pegawai dengan adanya loyalitas dan jenjang kepangkatan yang dimiliki pegawai menjadi modal dasar untuk menjalankan pekerjaanya sehingga peningkatan pengatahuan pegawai perlu menjadi perhatian agar perkerjaanya dapat diselesaikan dengan sebaikbaiknya. Analisis hasil wawancara menegaskan bahwa pengetahuan pegawai sangat berpegaruh terhadap pelaksanaan tugasnya. Hal ini dikarenakan penempatan pegawai sesuai dengan latar belakang pendidikan pegawai. Untuk meningkatkan pengetahuan pegawai, maka dibutuhkan pengalaman dan pelatihan-pelatihan serta keikutsertaan pegawai dalam berbagai kegiatan workshop.

Dapat disimpulkan bahwa pegawai Sekretariat Daerah Kabupaten Barru ditempatkan sesuai dengan latar belakang pendidikannya sehingga pegawai memiliki pengetahuan yang cukup dan terampil dalam menjalankan tugasnya sehingga pegawai tidak merasa terkendala menjalankan tugasnya.

\section{Keterampilan Pegawai}

Keterampilan yang memadai untuk meningkatkan kompetensi dapat tercapai. Keterampilan kerja dapat dicapai bila didukung dengan adanya pengalaman kerja yang kontinu dan seringnya mengikuti pendidikan dan 
pelatihan, baik itu Diklat yang bersifat struktural maupun Diklat-diklat yang bersifat teknis. Skill atau keterampilan merupakan salah satu unsur yang sangat penting dalam menunjang pelaksanaan kegiatan kerja. Hal ini sangat berpengaruh karena dengan keterampilan seorang pegawai dapat dengan mudah mengatasi atau mengantisipasi kendala-kendala yang muncul dan dengan keterampilan yang dimiliki akan lebih mudah menyelesaikan pekerjaan dibanding dengan pegawai yang tidak memiliki keterampilan.

Keterampilan merupakan salah satu faktor utama dalam usaha mencapai kesuksesan bagi pencapaian tujuan organisasi. Dengan adanya peningkatan keterampilan pegawai, maka hal tersebut akan mempengaruhi keahlian pegawai dalam melaksanakan tugasnya. Gibson (1998) mendefinisikan keterampilan sebagai, "Kecakapan yang berhubungan dengan tugas yang dimiliki seseorang dalam waktu yang tepat".

Analisis hasisl wawancara menegaskan bahwa keterampilan pegawai sangat berpengaruh terhadap kinerjap pegawai. Keterampilan yang dimiliki pegawai membuat mereka cakap dan terampil dalam melaksanakan tugasnya. Keterampilan pegawai sangat penting mengingat keahlian pegawai terhadap tugasnya sangat berdampak pada kualitas kerja pegawai. Kemudian analisis hasil wawancara menegaskan bahwa untuk dapat menjalankan tugas pokok dan fungsi pegawai dengan baik maka perlu diberikan pelatihan, bimbingan teknis terkait dengan bidang kerjanya agar pegawai terampil melaksanakan tugasnya. Tanpa keterampilan yang memadai terhadap tugasnya, tentunya akan berpengaruh terhadap kinerja pegawai.

Dapat disimpulkan bahwa keterampilan pegawai Sekretariat Daerah Kabupaten Barru belum optimal sehingga perlu adanya peningkatan keterampilan pengawai melalui berbagai kegiatan Dikat dan bimbingan khusus agar pegawai dapat menjalankan tugas dan fungsi pokoknya dengan sebaikbaiknya. 


\section{KESIMPULAN}

Kemampuan kerja pegawai Sekretariat Daerah Kabupaten Barru belum optimal dilihat dari kompetensi, kondisi kesehatan pegawai, pengetahuan dan keterampilan pegawai. Kompentensi pegawai belum maksimal yang disebabkan karena kurangnya pengetahuan dan keterampilan yang dimiliki sehingga kurang terampil dan cakap dalam menjalankan tugasnya. Sedangkan kondisi kesehatan sangat berpengaruh terhadap kinerja pegawai karena kesehatan pegawai yang baik akan memperlancar pekerjaan yang menjadi tugas dan tanggung jawabnya. Olehnya itu disarankan kepada Kepala Sekretariat Daerah Kabupaten Barru agar kemampuan kerja pegawai lebih ditingkatkan dengan cara meningkatkan kompetensi, pegetahuan, dan keterampilan pegawai melalui pemberian pelatihan-pelatihan yang terkait dengan tufoksi.

\section{REFERENSI}

Gibson, James L. (1998). Organisasi dan Manajemen Terjemahan Ichayaudin Zuhad. Jakarta:Erlangga.

Mangkunegara, A.P. (2000). Manajemen Sumber Daya Manusia, Bandung. PT, Remaja Rosdakarya.

Peraturan Pemerintah Nomor 3 tahun 2007 tentang Laporan Penyelenggaraan Pemerintahan Daerah (LPPD)

Peraturan Daerah Kabupaten Barru Nomor 4 Tahun 2008 tentang Pembentukan Organisasi dan Tata Kerja Sekretariat Daerah dan Sekretariat Dewan Perwakilan Rakyat Daerah Kabupaten Barru.

Robbins, Stephen P. (2006). Perilaku Organisasi. Edisi kesepuluh. Jakarta: PT Indeks Kelompok Gramedia.

Spencer, M. Lyle \& Spencer, M. Signe, (1993). Competence at Work. Canada: John Wiley \& Sons, Inc.

Undang-undang Nomor 36 Tahun 2009 tentang kesehatan. 